\title{
Relationship between incidence of Leucinodes orbonalis (Guenee) and Chlorophyll content in leaves of Brinjal (Solanum melongena $\mathrm{L}$.)
}

\author{
Showket. A. Dar ${ }^{1 *}$, A. R. Wani ${ }^{1}$, Shahid A. Padder $^{2}$, T. A. Raja ${ }^{3}$, Sheikh. Mehraj ${ }^{4}$ S. H. \\ Khan $^{5}$
}

*Department of Entomology, ${ }^{1}$ Division of Agricultural Entomology, ${ }^{2}$ Division of Plant Microbiology, ${ }^{3}$ Division of Agricultural statistics, ${ }^{4}$ Division of Fruit science, ${ }^{5}$ Division of vegetable science, Sher-e-Kashmir University of Agricultural Sciences and Technology, Kashmir - 190025, INDIA

*Corresponding author. E-mail: showketdar43@gmail.com

Received: January 16, 2015; Revised received: June 26, 2015; Accepted: July 21, 2015

Abstract: The present study on biochemical basis of resistance against Leucinodes orbonalis infestation was conducted during the year 2011-2012. The results revealed that highest chlorophyll-'a'- content of $0.497 \mathrm{mg} / \mathrm{gfw}$ was recorded in the susceptible genotype SHB-1.The lowest amount of 0.319 and $0.381 \mathrm{mg} / \mathrm{gfw}$ was observed in the resistant genotypes Brinjal-85 and Local long respectively, which were significantly different from other evaluated genotypes. The chlorophyll 'a'content was positively correlated with the brinjal shoot and fruit borer infestation. The highest chlorophyll -'b'- content of $0.442 \mathrm{mg} / \mathrm{gfw}$ was recorded at 70 DAT (days after transplanting). The amount of chlorophyll -'b'- varied significantly among the genotypes at different ages and decreased with the age of crop. The average highest amount of chlorophyll -'b'- was estimated in the genotype SBH-1 which was significantly at par with hybrid SBH-2. The lowest chlorophyll -'b'- content was recorded at 40 DAT in the genotype Brinjal-85 followed by Local Long. The lowest amount of total chlorophyll was estimated in the resistant variety as compared to susceptible therefore exhibiting lowest level of infestation.

Keywords: Brinjal, Biochemical, Chlorophyll, Pest, Resistance

\section{INTRODUCTION}

Brinjal (Solanum melongena L.) also known as aubergine belonging to the family "Solanaceae", is one of the common and popular vegetables grown throughout the world. The crop is extensively damaged by different insect pests and important pests among them are shoot and fruits borer (Leucinodes orbonalis Guenee), jassids (Amrasca devastans Dist.), flea beetle (Peylliodes brettinghami Maulik), Epilachna beetle (Epilachna spp.) and aphids (Aphis gossypi Glover) (Shukla and Khatri, 2010). However in Kashmir valley, L.orbonalis Guenee is one of the major pests of the brinjal causing considerable damage every year (Dar et al., 2014). The damage caused by L. orbonalis starts soon after transplanting of seedling and continues till the harvest of the fruit. The newly hatched larvae bore into the petiole and midrib of the large leaves as well as young tender shoots, close the entry holes with their excreta and feed inside of the fruit (Butani and Jotwani, 1984; Dar et al., 2014). Attempts have been made to control this notorious pest with the use of different insecticides. With the growing realization of hazards and side ill effects connected with the indiscriminate use of pesticides, entomologists have developed integrated pest management programme to maintain the pest population at level below those causing economic injury. According to Atwal and Singh (1989) a thorough knowledge about the economic significance of pest needs to be gained in terms of level of pest population, the extent of injury and consequent loss as prerequisite for development of management schedules for any pest. A chemical component like chlorophyll is considered as a yield determining component and a number of different types of chlorophylls occur in the plant kingdom, among them the chlorophyll -a- is of universal occurrence (Strain, 1994).

Since, the information regarding the relationship between L.orbonalis incidence and chlorophyll content are limited. The experiment was undertaken to find the interrelationship between incidence of L.orbonalis and leaf chlorophyll content of brinjal ( $S$. melongena) during $2011-12$. This research article provides a view of importance biochemical content common among plants. Therefore, close examinations of plant chemical characteristics are explained that contribute to pest resistance. In many cases it is obvious that the biochemical factors are more important than morphological and physiological factors in conferring non-preference and antibiosis. Some biochemical constituents may act as feeding stimuli for insects. Occurrence at lower concentration or total absence of such biochemical leads to non-preference, a form of insect resistance. The biochemical constituents are available in brinjal 
and these biochemical constituents possess insect resistant properties.

\section{MATERIALS AND METHODS}

Studies on the effect of different total chlorophyll content in the leaves of different genotypes of brinjal was conducted during Kharif season 2011-12 at experimental field of Division of Vegetable Sciences, Sher-e-Kashmir University of Agricultural Science and Technology of Kashmir, Shalimar (Jammu and Kashmir). Twelve brinjal genotypes were evaluated and the experiment was laid out in the Randomized Block Design (RBD) with three replications. Seedlings were spaced at $60 \times 45 \mathrm{~cm}$ in each individual plot of size $16 \times 12 \mathrm{~m}^{2}$. Regular inter-cultivation practices and need based irrigation were performed. Leaf chlorophyll was estimated from the third leaf count from the top and from the shoots at $10 \mathrm{~cm}$ above the growing. The leaves were randomly selected from 5 different plants per plot of each genotype in the three replications. The leaf and shoot pigments were estimated and statistical analysis was done according the Gomez and Gomez (1984). ). At the same time the percentage of the infestation were recorded and were graded from the mean percentages, following the method of Mukhopadhay and Mendal (1984). Chlorophyll content was estimated by the method of Yoshida et al. (1978).

\section{RESULTS AND DISCUSSION}

Chlorophyll -a- content of third leaf of different brinjal genotypes varied significantly from 0.43 (resistant), 0.47 (moderately resistant), 0.53 (tolerant), 0.57 (moderately susceptible), 0.62 (susceptible) and 0.69 (highly susceptible) at 40, 70 and 100 DAT, respectively (Table 1). Amount of chlorophyll -a- also varied significantly with the age of the brinjal plant having highest at 100 DAT (0.72) and lowest at 50 DAT (0.43), which was similar to that of 40 DAT (Fig. 2 \&Table 1). The correlation coefficient of chlorophyll -a- content of the third leaf between 40 and 70 DAT were 0.97 and significant at $1 \%$ confidence level; but between 70 and 100 DAT (0.298) were insignificant. Besides, the infestation pattern of brinjal fruit and shoot borer with respect to chlorophyll -a- were significantly different at 40, 70 and 100 DAT. A strong positive correlation was observed between the pest infestation and chlorophyll -a- similarly the resistance was significantly positively correlated with the activity of peroxidase (POD) and the content of total chlorophyll $(P<0.05)$ as observed by Zhou et al. (2012). On the basis of average value lowest chlorophyll -a- content was observed in the Brinjal-85 (0.25), which significantly different from the other varieties/hybrids, except Local Long. Similarly, the average highest amount of chlorophyll -a- content was recorded in Shalimar Brinjal Hybrid-1(0.69) which was statistically different from all varieties/genotypes except Shalimar Brinjal Hybrid-2(0.63). The chlorophyll -a- content was positively correlated $(0.87)$ with brinjal shoot and fruit borer infestation i.e., the varieties Local Long, Brinjal-85, Dilruba-2 and Shalimar Brinjal Long-208 with purple coloured leaves and flowers at 70 DAT were less susceptible to brinjal shoot and fruit borer, than those with dark purple to light green leaves (Shalimar Brinjal Hybrid-1 and Shalimar Brinjal Hybrid-2). Asathi et al. (2002) found a strong positive correlation between the L.orbonalis infestation and chlorophyll content among five different genotypes in Chhattisgarh (India). However, Pathak (1961) and Kabir et al. (1989) reported that dark coloured leaves are more susceptible than purple coloured leaves, except varieties viz, BLO-100 and Islampuri in which infestation increased with increase in chlorophyll -a- content, but in present investigations the genotypes with dark coloured leaves were found comparatively less susceptible to borer damage.

Among the different varieties/genotypes used under investigation chlorophyll - $b$ - content of third leaf varied significantly from $0.31(\mathrm{R}), 0.40(\mathrm{MR}), 0.39(\mathrm{~T})$, $0.41(\mathrm{MS}), 0.42(\mathrm{~S})$ and $0.45(\mathrm{HS})$ at 40,70 and 100 DAT, respectively. Amount of chlorophyll -b- also varied significantly with age of the brinjal plant with highest at 70 DAT (0.45) and lowest at 40 DAT (0.31). The chlorophyll -b- at 40 DAT was similar to the content at $100 \mathrm{DAT}$. The average highest content of chlorophyll -b- was observed in Shalimar Brinjal Hybrid-1 differs significantly, followed by Shalimar Brinjal Hybrid-2. The lowest average chlorophyll -b- was recorded in variety Brinjal-85 followed by Local Long, and were statistically at par with each other but different from rest of the genotypes taken under investigation. The chlorophyll -b-content was positively correlated with borer infestation i.e., infestation increases linearly with increase in chlorophyll -b- content (Shalimar Brinjal Hybrid-1 and Shalimar Brinjal Hybrid-2), and decreased at certain points in some varieties, this in contradiction with the findings of Teotia and Lal (1970), who found a negative correlation between the chlorophyll -b- and borer damage. Besides, the infestation pattern of brinjal fruit and shoot borer were different at 40, 70 and 100 DAT with respect to the chlorophyll -a- and -b - (Fig. 2). On the basis of average value lowest chlorophyll -b- content was observed in the Brinjal-85 (0.58), which was also significantly different from the other varieties/hybrids, except Local Long. Similarly, the average highest amount of chlorophyll -b- content was recorded in Shalimar Brinjal Hybrid-1, which was statistically different from all varieties except Shalimar Brinjal Hybrid-2. The chlorophyll -b- content was positively correlated $(0.87)$ with brinjal shoot and fruit borer infestation i.e., the varieties with light purple to dark purple coloured leaves at 70 DAT were less susceptible to brinjal shoot and fruit borer, than those with light green leaves in which there is high content 
Table 1. Leaf chlorophyll content (mg/gfw) of 12 selected brinjal varieties/genotypes at different ages (40, 70 and 100 days after transplantation).

\begin{tabular}{|c|c|c|c|c|c|}
\hline \multirow[t]{2}{*}{ Varieties/hybrids } & \multicolumn{3}{|c|}{$\begin{array}{l}\text { Mean chlorophyll content at } 40,70 \text { and } 100 \\
\text { days after transplanting } \\
\text { ( } \mathrm{mg} / \mathrm{gfw} \text {; } \mathrm{mg} \text { per gram fresh weight). }\end{array}$} & \multirow[t]{2}{*}{$\begin{array}{l}\text { L.orbonalis } \\
\text { infestation } \\
(\%)\end{array}$} & \multirow[t]{2}{*}{$\begin{array}{l}* \text { Level of } \\
\text { resistance }\end{array}$} \\
\hline & $\begin{array}{l}\text { Ch lor o o - } \\
\text { phyll 'a' }\end{array}$ & $\begin{array}{l}\text { Chlorophyll } \\
\text { 'b' }\end{array}$ & $\begin{array}{c}\text { Total } \\
\text { chlorophyll } \\
(\mathbf{a}+\mathbf{b})\end{array}$ & & \\
\hline Shalimar Brinjal Long-217 & $0.415^{\mathrm{b}}$ & $0.278^{\mathrm{a}}$ & $0.693^{\mathrm{c}}$ & $\begin{array}{c}6.70^{\mathrm{e}} \\
(14.55) \\
4.60^{\mathrm{b}}\end{array}$ & $\begin{array}{l}\text { Tolerant } \\
\mathrm{F} \text { a i r } 1\end{array}$ \\
\hline Local Long & $0.381^{\mathrm{b}}$ & $0.293^{\mathrm{b}}$ & $0.647^{\mathrm{b}}$ & $\begin{array}{l}(12.62) \\
7.50^{\mathrm{f}}\end{array}$ & Resistant \\
\hline Brinjal Oblong & $0.421^{\mathrm{b}}$ & $0.406^{\mathrm{c}}$ & $0.777^{\mathrm{d}}$ & $\begin{array}{c}(15.88) \\
7.50^{\mathrm{f}}\end{array}$ & Susceptible \\
\hline Brinjal Purple Long & $0.439^{\mathrm{c}}$ & $0.318^{\mathrm{b}}$ & $0.759^{\mathrm{d}}$ & $\begin{array}{c}(15.88) \\
5.34^{\mathrm{c}}\end{array}$ & Susceptible \\
\hline Shalimar Brinjal Purple Long-42 & $0.377^{\mathrm{b}}$ & $0.286^{\mathrm{b}}$ & $0.663^{\mathrm{b}}$ & $\begin{array}{c}(13.34) \\
9.10^{\mathrm{g}}\end{array}$ & $\begin{array}{l}\text { Tolerant } \\
\mathrm{H} \text { i g h l y }\end{array}$ \\
\hline Shalimar Brinjal Hybrid-1 & $0.497^{\mathrm{d}}$ & $0.375^{\mathrm{c}}$ & $0.872^{\mathrm{f}}$ & $\begin{array}{l}(17.53) \\
4.96^{\mathrm{b}}\end{array}$ & susceptible \\
\hline Shalimar Brinjal Purple Round-8 & $0.383^{\mathrm{b}}$ & $0.276^{\mathrm{a}}$ & $0.709^{b}$ & $(12.82)$ & Fairly resistant \\
\hline Dilruba-2 & $0.468^{\mathrm{c}}$ & $0.346^{\mathrm{c}}$ & $0.814^{\mathrm{e}}$ & $\begin{array}{l}6.97^{\mathrm{e}} \\
(15.75) \\
2.34^{\mathrm{a}}\end{array}$ & Tolerant \\
\hline Brinjal-85 & $0.319^{\mathrm{a}}$ & $0.271^{\mathrm{a}}$ & $0.589^{\mathrm{a}}$ & $\begin{array}{l}(6.91) \\
6.20^{\mathrm{d}}\end{array}$ & Resistant \\
\hline Shalimar Brinjal Long-208 & $0.407^{\mathrm{a}}$ & $0.311^{\mathrm{b}}$ & $0.668^{\mathrm{b}}$ & $\begin{array}{l}(14.37) \\
7.70^{\mathrm{f}}\end{array}$ & Tolerant \\
\hline $\begin{array}{l}\text { Shalimar Brinjal Hybrid-2 } \\
\text { Shalimar Brinjal Purple Round- }\end{array}$ & $0.441^{\mathrm{d}}$ & $0.442^{\mathrm{d}}$ & $0.883^{\mathrm{f}}$ & $\begin{array}{l}(16.08) \\
5.10^{\mathrm{c}}\end{array}$ & Susceptible \\
\hline 1 & $0.349^{\mathrm{a}}$ & $0.248^{\mathrm{a}}$ & $0.597^{\mathrm{a}}$ & $(13.02)$ & Tolerant \\
\hline$C D_{(P=0.05)}$ & $\mathbf{0 . 0 5 3 7}$ & $\mathbf{0 . 0 3 2 1}$ & 0.0438 & $\mathbf{0 . 3 7}$ & \\
\hline
\end{tabular}

Each value is the mean of three replicates;Figures in parentheses are arcsine-transformed values. In a column, means followed by the same letter (s) are not significantly different by DMRT $(\mathrm{P}=0.05)$
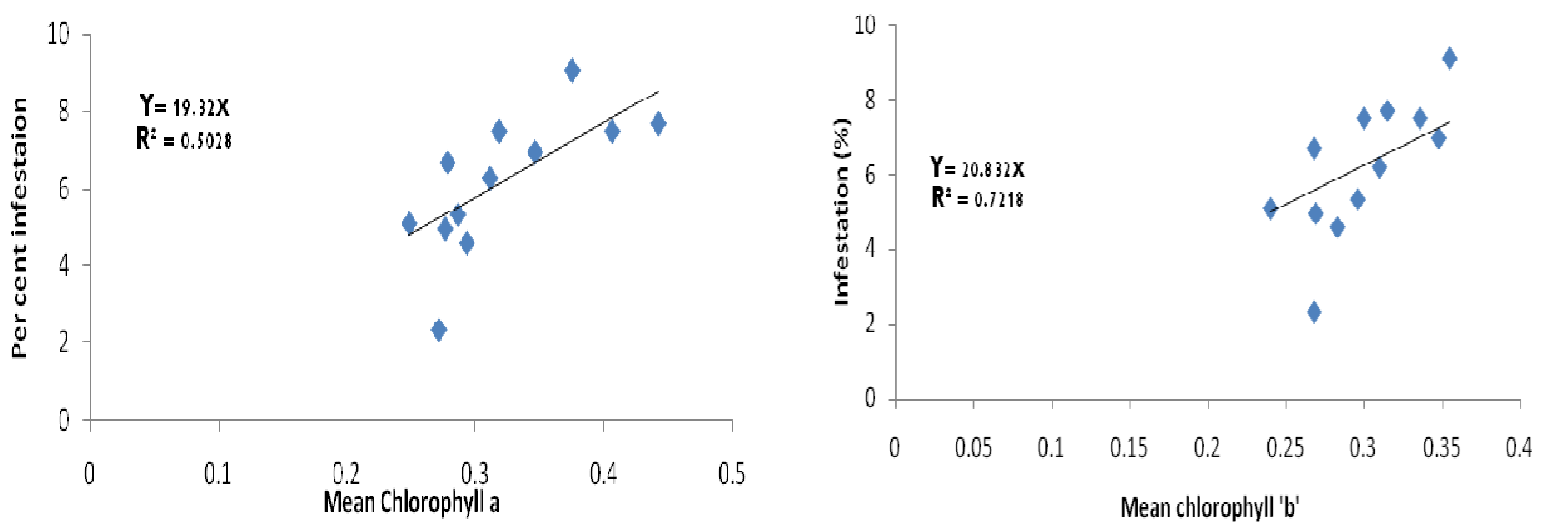

Fig. 1. Relationship between chlorophyll ' $a$ ' and ' $b$ ' content and brinjal shoot and fruit borer infestation at different days after transplantation.

of chlorophyll -b-. However, in contrast to this Nilam and Patel (2012) observed that chlorophyll exhibited a non-significant but negatively correlated with infestation level of E. vittella to shoot and fruit.
Average total chlorophyll content of different brinjal hybrids/varieties ranged from 0.823 (Shalimar Brinjal Hybrid-1) to $0.559 \mathrm{mg} / \mathrm{gfw}$ at $40 \mathrm{DAT}$; 0.0 .598 to $0.627 \mathrm{mg} / \mathrm{gfw}$ at $70 \mathrm{DAT}$ and from 0.547 to $0.501 \mathrm{mg} /$ 


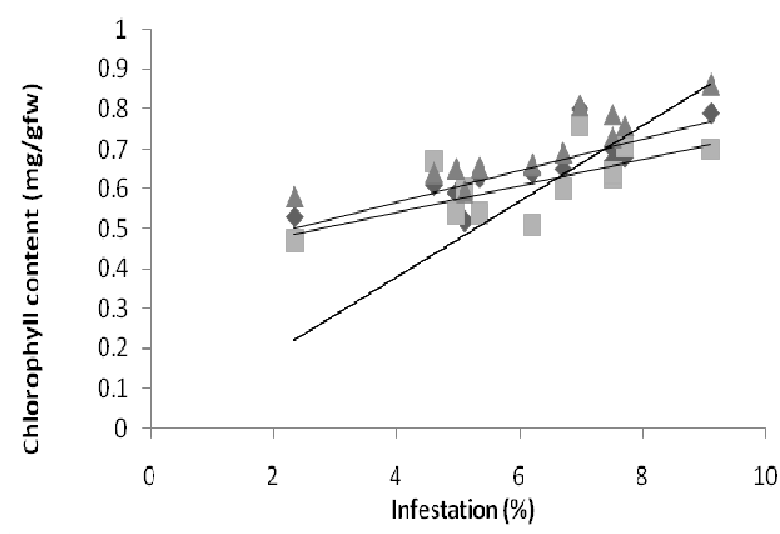

Fig. 2. Infestation pattern of the brinjal shoot and fruit borer in brinjal at 40, 70 and 100 days after transplanting.

gfw at 100 DAT. Chlorophyll content varied significantly among hybrids and varieties at different ages of the crop (Fig. 2) which is also in conformity with the results of Sindhu (1992) in variety P-8 (0.026mg/g) and Ingale and Patil (1997) in variety PBR-91-1 $(0.126 \mathrm{mg} / \mathrm{g})$. Elanchezhyan et al. (2008) observed the maximum of total chlorophyll $1.86(\mathrm{mg} / \mathrm{g})$ in the Bejo Sheetal (HS) exhibited the L.orbonalis infestation of the $35.7 \%$.Total chlorophyll content is higher at fruiting stage than at the vegetative stage irrespective of the varieties. Asathi et al. (2002) reported that chlorophyll at vegetative stages ranged from $0.009 \mathrm{mg} / \mathrm{g}$ to $0.045 \mathrm{mg} / \mathrm{g}$ while at fruiting stage it varied from 0.020 to $0.061 \mathrm{mg} / \mathrm{g}$. Besides, the infestation pattern of L.orbonalis varied among different hybrids/varieties. The total average amount of chlorophyll content was positively correlated with borer infestation at 100 DAT, and lowest at 40 DAT. Similar results in brinjal were also reported by Murugesh (1997).The apparent fruits and leaf colour is dependent upon the total chlorophyll content, and that chemical constituents (Total sugars) were found to be maximum in Shalimar Brinjal Hybrid-1 and Shalimar Brinjal Hybrid-2, thus contributing towards susceptibility to the L.orbonalis, while as the varieties Brinjal-85 and Local long were resistant containing maximum of total phenol content and comparatively less total chlorophyll content.

In the present work chlorophyll content had a positive correlation with the L. orbonalis infestation which is in conformity with the Saxena and Diwakar (2012) who found that due to infestation of Henosepilachna total chlorophyll get decreased which means that brinjal genotype having lowest chlorophyll cannot be preferred by $L$. orbonalis, similarly Prabhu et al. (2009) also observed a correlation between chlorophyll content and brinjal shoot and fruit borer. The correlation coefficient between total chlorophyll content and L.orbonalis infestation at 40 and 70 significant, 40 and 100 significant; 70 and 100 DAT were non-significant. The average highest content of total chlorophyll were recorded in Shalimar Brinjal Hybrid-1; while as, average lowest amount of chlorophyll content were recorded in Brinaj1-85, which is in contradict with findings of Pathak (1961) and Kabir et al. (1989) who observed the average lowest amount of total chlorophyll content in susceptible variety Nayankajal which recorded the highest infestation.

The total chlorophyll content in varied significantly among the different genotypes/varieties. The maximum chlorophyll -a- and -b- and brinjal shoot and fruit borer damage were found in Shalimar BrinjalHybrid-1.The correlation coefficient between chlorophyll -a- and -b - with borer attack were positive and high as compared to the resistant genotypes were lowest content of chlorophyll -a- and -b- were found, exhibited week correlation with the borer damage. At 40 DAT, the maximum of infestation of 4.25 and 4.11 per cent were recorded in Shalimar Brinjal Hybrid-1 and Shalimar Brinjal Hybrid-2 having the chlorophyll -a- content of 0.387 and 0.178 (mg/gfw), respectively.

With the advance in the age of the crop the average of the total chlorophyll increases with the advance in vegetative stage of the crop, but decreases with maturity of the crop that corresponds with the decrease in the shoot infestation of the brinjal. However, the chlorophyll -b-also increases with the vegetative stage of the crop but is comparatively lower than the chlorophyll -a - damage by L.orbonalis. However, it was noted that percentage of total chlorophyll content was higher in locally developed hydrids therefore suffering more borer infestation in shoots as compared to the rest of the commercially cultivated brinjal varieties having comparatively less total chlorophyll content. Identification of suitable molecular markers which are linked with resistance.

\section{Conclusion}

From the results, it is clearly evident that genotypes viz, Shalimar Brinjal Hybrid-1 and Shalimar Brinjal Hybrid-2 having higher chlorophyll content received higher infestation, whereas genotypes like Local Long and Brinjal-85 with lower total chlorophyll content received lower infestation of $L$. orbonalis in both shoot and fruit. Therefore, the results of the present study suggested that genotypes having lower chlorophyll content in leaves could be utilized in the breeding programme for the development of BSFB resistant varieties in brinjal.

\section{ACKNOWLEDGEMENT}

Authors are highly thankful to the SKUAST-K, Shalimar for providing the necessary facilities to conduct the research.

\section{REFERENCES}

Asathi, B.S., Sarnaik, D.A., Thakur, B.S. and Guhey, A. (2002). Shoot and fruit borer incidence as influenced by total phenol and chlorophyll content in round fruited brinjal varieties. Orissa Journal of Horticulture, 30 (2): 100-104

Atwal, A.S. and Singh, B (1989). Pest population and 
assessment of crop losses. Pub. By Indian Council of Agricultural Research, New Delhi. p. 131.

Butani, D.K. and Jotwani, M.G, (1984). Insects in vegetables. Periodical Expert Book Agency. D 42, Vivek Vihar -110032. India. pp: 293.

Dar, S.A., Abdul. R. Wani, A.R., Mir, S.H., Nehru, R.K. and Jeelani, M.I. (2014). Relationship between morphological characters of different brinjal genotypes and extent of infestation by L. orbonalis. Green Farming, 6 (5): 1-5

Elanchezhyan, K., Murali, R.K. and Rajavel, D.S, (2008). Biochemical basis of resistance in brinjal genotypes to shoot and fruit borer (Leucinodes orbonalis Guen.). Journal of Entomological Research, 32 (2): 101-104

Gomez, K.A. and Gomez, A.A, (1984). Statistical procedures for Agricultural Research. John Wiley and Sons, New York. pp.680

Ingale, B.V. and Patil, S.J, (1997). Inheritance of fruiting pattern in brinjal. J. of Maharashtra Agric. Univ. Publ, 21: $250-257$

Kabir, M.H., Sardar, M.A. and Hussain, M, (1989). Some physical and chemical aspects of various germplasm of mustard influencing abundance of aphids, L. erysimi (Kalt.). Nuci.Sci.Appl.1:82-85

Mukhopadhyay, A. and Mandal, A, (1994). Screening of brinjal (Solanum melongena) for resistance to major insect pests. Indian journal of Agriculture Science, 64:798-803

Murugesh, T, (1997). Ecology and Management of shoot and fruit borer, Leucinodes orbonalis Guenee and spotted leaf beetle, Henosepilachna Vigintioctopunctata (Fabricius) of brinjal. M.Sc. (Ag.) Thesis, Tamil Nadu Agriculture University, Killikulam.

Nilam, R. and Patel, J. J. (2012). Resistance sources of okra genotypes/cultivars to shoot and fruit borer (Earias vittella Fabricius). AGRES - An International e Journal,
1(4): 497-503

Pathak, M.D (1961), Preliminary notes on differential response of yellow and brown sarson and rai to mustard aphid (L.erysimi, Kalt). Indian Oilseeds Journal, 5:39-44

Prabhu, M., Natarajan, S., Veeraraganathatham. D. and Pugalendhi, L. (2009). The biochemical basis of shoot and fruit borer resistance in interspecific progenies of brinjal (Solanum melongena). Eur Asian J Biosc, 3: 50-57

Saxena, R. and Diwakar. R, (2012). Biochemical Analysis of Chlorophyll Content of Brinjal Leaves. VEGETOS, 25 (2): $83-85$

Shukla, A. and Khatri, S.N. (2010). Studies on the effect of different food plants on development of brinjal shoot and fruit borer, Leucinodes orbonalis (Guenee). The Bioscan, 2: 441-450

Sindhu, S. (1992). Comparative reaction to insecticides of populations of the cotton bollworm from various cotton- growing zones. In: Ustoichivost' vreditelei $K$. Khimicheskim sredstvam zashehity rastenii (ed. Zil'bermints, I.V., Smirnova, A.A. and Matov, G.N.) Moscow, USSR, pp: 76-82

Strain, H.H. (1994). Chloroplast pigments. Ann.Biochem, 13: 591-610

Teotia, T.S.S. and Lal, O.P. (1970). Differential response of different varieties and strains of oleiferous Brassicae to aphids, L.erysimi (Kalt.). Journal of Science and Technology, 8: 219-226

Yoshida, S., Formo, A.D. Cock, A.J. and Gomes, A.K. (1978). Laboratory manual for physiological studies of rice. $3^{\text {rd }}$ ed. IRRI, Los Banos, Philippines, pp. 43-45

Zhou. B., Zhixia. C., Liang. D., Xueling. Y and Ning. L, (2012). Correlation between resistance of eggplant and defense-related enzymes and biochemical substances of leaves. African Journal of Biotechnology, 11(74): 13896 $-13902$ 